\title{
Strategies for Revitalisation of Semarang Heritage Area: a Stakeholders Perspective
}

\author{
Ferry Hermawan ${ }^{1 *}$, Kinan Kartika Sani ${ }^{2}$, and Bambang Purwanggono ${ }^{2}$ \\ ${ }^{1}$ Diponegoro University, Civil Engineering Department, Prof. Sudharto SH Semarang, Indonesia \\ ${ }^{2}$ Diponegoro University, Industrial Engineering Department, Prof. Sudharto SH Semarang, Indonesia
}

\begin{abstract}
The old City of Semarang as a heritage area has a significant historical value. Since Independence Day of Indonesia, that area has been abandoned and unoccupied without maintenance. Lack of activity makes the heritage area become a dead city and broad to some issues, environmental, buildings defects, social and institutional governance. The revitalisation activities of cultural heritage in some countries are unique to the technical, socio-economic and cultural aspects. Often the parties could not be generalised due to issues of the authorities, financial capabilities, readiness of stakeholders, and the complexity of its heritage buildings. The research aims to formulate a revitalisation strategy for the heritage area of Semarang to a World Heritage from the stakeholders' perspective through a qualitative, descriptive method. The research strategy uses Focus Group Discussion, semi-structured interviews and field observations were involving the parties on old city revitalisation projects. The results provide the strategy for revitalisation of Semarang heritage area. Stakeholders perspectives become a lesson learned for future strategic management in heritage buildings, either private or public property
\end{abstract}

\section{Introduction}

The potential of Semarang Old Town as tourism object can be seen from its historical values, as it was a fortress and trade centre of the Dutch [1]. In the 19th-20th century, Semarang Old Town was an international trade city because it was supported by the global trade of sugar, in addition to its location which was near the port and railway station [2]. The rapid growth of the economy has made Semarang Old Town as an administrative and financial centre with the existence of office buildings and banks. The Old Town degraded its function in 1980-1990 since there was no activity there [3]. Since Independence, the Indonesian Government took over all trade business from the Dutch, government offices as well as other buildings [4]. The building owners started to abandon their buildings and leave them unoccupied. The abandoned old town of Semarang had led this town into problems. The problems were (1) Physical condition of the buildings, (2) socio-cultural problems and public welfare as the town was transformed into red light district and bars, (3) environmental issues such as floods and tidal floods that destroyed the buildings from its

\footnotetext{
*Corresponding author: ferry.hermawan@live.undip.ac.id
} 
architectural and structural aspects, (4) infrastructure problems related to damaged roads, short-circuits, and blocked drainages [5]. The complex issues in the Old Town were due to high maintenance cost, poor public awareness on preserving cultural heritage buildings, and poor implementation of the Law on a cultural heritage building.

The Municipality of Semarang has initiated building preservation program since the issuance of the Mayor Decree of Semarang No. 646/50/1992 on Conservation of Historic Buildings. Semarang Old Town was on UNESCO World Heritage Tentative List in 2015. It was a list containing the names of property which were considered as a cultural heritage from various countries in the world and nominated for world heritage sites by UNESCO[6]. The Municipality of Semarang is trying various effort to include Semarang into the list of UNESCO world heritage site in 2020 [1], one of them is by revitalising the old buildings. The revitalisation of Semarang Old Town has been planned since 2003 [7]. As a long-term plan, revitalisation is carried out to preserve the historic buildings. The revitalisation process is an effort of the Municipality of Semarang to relive the function of this abandoned town. Revitalisation can also increase the added value so that Semarang Old Town can improve its tourism attractiveness.

As one of world heritage sites, a cultural heritage should have the Outstanding Universal Value (OUV), which makes it unique. OUV is used as the assessment criteria for determining a cultural heritage to be listed in world heritage. UNESCO has determined 3 (three) criteria for cultural heritage to obtain OUV, one of which is (1) meeting one or more of 10 criteria. Semarang Old Town meets two of 10 criteria on point 2 and 4 [3]. (2) meeting the criteria of authenticity or integrity and (3) must have an adequate protection and management system to its safeguarding [6]. The implementation of revitalisation of Semarang Old Town must apply the assessment criteria to achieve the world heritage status. Learning from Jakarta Old Town, that failed to be nominated for a world heritage site since it is considered lack in presenting uniqueness and speciality of Colonial Town in South East Asia [8] and Jakarta bay reclamation [9]. Revitalisation strategy is needed to achieve the goals of this revitalisation. The experiences from many countries can be used as a reference in revitalising a historical area. Malacca Town and George Town are part of the Old Town which are successfully listed on the world heritage sites by UNESCO. Warmia Town in Poland is also a historical town which is successful in its revitalisation. The result is a guideline to revitalise historical areas in other regions.

Revitalisation strategy can be used as a solution to solve the problems in Semarang Old Town, so the goals of revitalisation can be achieved. The formulation of a revitalisation strategy needs the roles of many parties. The involvement of the stakeholders has the most significant role in regulating the implementation of Semarang Old Town revitalisation. The stakeholders who are directly involved have to be competent in their respective fields. The Government roles is considered as significant to direct the revitalisation in Semarang Old Town to avoid the past mistake happened to Jakarta Old Town Area. Therefore, a question raised is "to what extent the roles of the stakeholders in the revitalisation process of Semarang Old Town?". The involvement of the stakeholders would be implemented into a framework of revitalisation management of Semarang Old Town. The framework tends to craft the strategies of cultural heritage area as a reference to revitalise other regions.

\subsection{Experience of preservation heritage area in difference countries}

Each country has its way of preserving cultural heritage area and buildings. The abandoned cultural heritage area has made the community start to leave the town so that its function was decreasing. Town regeneration into an area with new opportunities can be carried out through conservation and rebuilding by proper planning [10]. 
An assessment of the environmental condition is needed to identify building performance after revitalisation [11]. The revitalisation of historic buildings into the form of hotel, café, and museum is expected to improve community welfare. Some heritage buildings in the cultural heritage sites which still have the authentic structures need to get individual attention and the best conservation. One of the causes of damage to historical buildings is poor maintenance operation system to extend the lifetime of the buildings. Further research reveals that it is the cause for building collapses [12]. Maintenance during the design process is required as a guideline of the initial maintenance plan [13].

The development of a historical city consists of spatial factors such as urbanistic (urban development/ urban planning) and architecture, historic building conservation and its structure, as well as socio-economic aspect [14]. These elements lead to a better explanation and revitalisation of the old town to be functional than other towns. Several preservation efforts in different countries are presented in Table 1.

Table 1. Cultural Heritage Preservation in Different Counties

\begin{tabular}{|c|c|c|}
\hline Preservation & Results of research & Location \\
\hline $\begin{array}{l}\text { They involve digital media into } \\
\text { the conservation of historical } \\
\text { building by using the Historical } \\
\text { Building Information Model } \\
\text { (HBIM). }\end{array}$ & $\begin{array}{l}\text { The result demonstrating a direct relationship between the } \\
\text { digital model and visualisation tools that is able to manage the } \\
\text { components of the architecture. The implementation of this } \\
\text { strategy is an effective way to preserve historical buildings by } \\
\text { providing information using a visualisation technique based on } \\
\text { augmented reality and virtual reality (AR and VR) }\end{array}$ & $\begin{array}{l}\text { Palace near } \\
\text { Turin, Italy } \\
{[15]}\end{array}$ \\
\hline $\begin{array}{l}\text { It was giving initiative for the } \\
\text { regeneration of historical towns } \\
\text { to regain the golden era so it } \\
\text { can improve the local } \\
\text { community's life. A heritage } \\
\text { site can survive when the local } \\
\text { population still exists. }\end{array}$ & $\begin{array}{l}\square \text { Zoning the conservation zone and buffer zone } \\
\square \text { Providing sidewalks for a pedestrian at the historical town } \\
\square \text { Using it as a tourism product } \\
\square \text { Proper management of heritage and tourism } \\
\square \text { Local community involvement in heritage conservation }\end{array}$ & $\begin{array}{l}\text { Malacca } \\
\text { and George } \\
\text { Town [16] }\end{array}$ \\
\hline $\begin{array}{l}\text { Removing the source of } \\
\text { revitalisation threats, } \\
\text { improving the technical } \\
\text { condition of urban structure, } \\
\text { ensuring better standard and } \\
\text { living for the locals, and } \\
\text { increasing the aesthetic value } \\
\text { of the revitalised area }\end{array}$ & $\begin{array}{l}\square \text { The result is revitalisation guideline, including: } \\
\square \text { Development of urbanistic pattern on the roads and } \\
\text { buildings } \\
\square \text { Development of urban structure by the historical solution } \\
\text { (improved urbanistic structure, human-being dimension) } \\
\square \text { Redesigning the architectural compositions by the original } \\
\text { estimation (building scale, zoning, materials, urban } \\
\text { characteristics) } \\
\square \text { Public space organisation in downtown (shops, services) } \\
\square \text { Identity reconstruction as an attraction of the downtown }\end{array}$ & $\begin{array}{l}\text { Warmia } \\
\text { Town in } \\
\text { Poland [14] }\end{array}$ \\
\hline $\begin{array}{l}\text { A graphic document can be } \\
\text { visualised by } 3 \mathrm{D} \text { model to } \\
\text { present to the community about } \\
\text { buildings that are considered as } \\
\text { historical }\end{array}$ & $\begin{array}{l}\text { It is deemed as one way to conserve the lost historical } \\
\text { buildings. 3D visualisation of building in the form of a graphic } \\
\text { document allows for complete recovery. }\end{array}$ & $\begin{array}{l}\text { Centelles } \\
\text { Palace in } \\
\text { Valencia, } \\
\text { Spain [17] }\end{array}$ \\
\hline $\begin{array}{l}\text { Implementation of HUL } \\
\text { (Heritage Urban Landscape) } \\
\text { approach }\end{array}$ & $\begin{array}{l}\text { Community Engagement Tools Inventories of cultural heritage } \\
\text { (tangible), compiling story (intangible mapping), Stakeholder } \\
\text { participation, visionary meeting, "community planning", } \\
\text { partnership } \\
\text { 1. Knowledge and Planning Tools } \\
\text { Inventories, Cultural mapping, the participation of the } \\
\text { community, "community planning"; Local Area Plans } \\
\text { (LAP); Planning Policy Guidance (PPG); HUL Analysis } \\
\text { 2. Regulatory Systems } \\
\text { National Spatial Development Strategy (NSDS), Zanzibar } \\
\text { Structural Plan (Zans-Plan), LAP } \\
\text { 3. Financial Tools by Grant (The Dutch Government) }\end{array}$ & $\begin{array}{l}\text { Zanzibar, } \\
\text { Tanzania } \\
{[18]}\end{array}$ \\
\hline
\end{tabular}


Building preservation presented in Table 1. can be used as a reference to revitalise cultural heritage area. The revitalisation of Semarang Old Town may refer to the conservation in Malaysia that is successfully listed on UNESCO world heritage sites in South East Asia. Moreover, conservation in Warmia Town can be used as a guide to implement revitalisation in Semarang Old Town Area. Another conservation effort is analysing method by conducting surveys on each building, as well as implementing HUL Toolkit in Zanzibar, Tanzania. Choosing the right method affects the success of cultural heritage preservation. Therefore, the roles of the parties involved in the revitalisation need to be integrated.

The Government has the authority and responsibilities to regulate a city. Regional autonomy requires the regional Government to regulate and manage its administrative and local community affairs to comply with the prevailing laws and regulations. Protection over historical buildings in a city is the right and authority of Regional Government. The intervention of regional Government on historical buildings includes conservation, restoration, revitalisation, reuse, renovation, and rehabilitation. According to Pickard [19], the Government can promote conservation-restoration, and rehabilitation in two ways: (1) Involving policies and procedures to persuade the private sector to invest in architectural heritage (dynamic approach). (2) Departing from the fact that, without government support, the private sector can decide that investment is not economically justified, so it creates the needs of financial incentives and subsidies (support approach). Pickard [19], also states that the evidence of the heritage building regeneration scheme using Public-Private Partnership (PPP) model yielded in 6 folds or more from public investment. Therefore, the partnership scheme needs to be introduced and considered in urban conservation and regeneration project to ensure the commitment of the public and private sectors in preserving their cultural heritage.

\subsection{Stakeholders engagement is a key success for heritage area revitalisation}

The stakeholders' engagement is significant to the success of historical area revitalisation. Experience from other countries regarding stakeholders' roles is identified in Table 2. Semarang Old Town revitalisation is inseparable from the roles of interdisciplinary professions. The relevant parties are the determinant factor for the success of the revitalisation process. The experience of area regeneration from different countries presented is evidence of the roles of the stakeholders in the success of the revitalisation process. The stakeholder involved in Semarang Old Town revitalisation project is the Regional Government of Semarang as the authority to regulate this city. Furthermore, the roles of architects, civil/structural engineer specialists in heritage building is the stakeholders who provide suggestions regarding building renovation during the revitalisation process of Semarang Old Town. Semarang Old Town Management Board (BPK2L), Cultural Heritage Expert Team (TACB), Building Structure Expert Team (TABG) supervise the implementation of revitalisation, so Semarang Old Town will not lose its identity. Other stakeholders involved in the revitalisation project of Semarang Old Town from the construction aspect is the contractors. Contractors as the executive construction project during the revitalisation process of Semarang Old Town are responsible for drainage system repair, public infrastructure improvement, and the completeness of street furniture. The different perspectives and opinions from the relevant parties need to be bridged to achieve the expected goals. 
Table 2. Roles of Stakeholders on Heritage Area Revitalisation in Various Countries $[20,21,16]$.

\begin{tabular}{|l|l|}
\hline \multicolumn{1}{|c|}{ Stakeholders } & \multicolumn{1}{|c|}{ Location of revitalisation } \\
\hline Public and Private Sectors & $\begin{array}{l}\text { Location: Downtown Khedive Cairo, Egypt } \\
\text { The physical revitalisation of the Downtown Khedive Cairo directed by } \\
\text { the public sector. Other socio-economic and cultural aspects are taken } \\
\text { over by non-state stakeholders with the condition that it is by their } \\
\text { perspectives and interests. }\end{array}$ \\
\hline Government, Academician & $\begin{array}{l}\text { Location: Tire, Turkey } \\
\text { The Government of Tire cooperates with universities to revitalise the } \\
\text { historical urban area in Tire (Tire District). The universities started to } \\
\text { revitalise some buildings featuring the new perspectives and suggestions } \\
\text { from architecture students regarding a new function of the weathered and } \\
\text { abandoned building. }\end{array}$ \\
\hline $\begin{array}{l}\text { Regional Government, public } \\
\text { and private sectors, } \\
\text { communities }\end{array}$ & $\begin{array}{l}\text { Location: Malaysia } \\
\text { Public participation in conservation and regeneration of the historical } \\
\text { area with decision making regarding the future of their city is a crucial } \\
\text { matter. It is based on the consideration that the locals are the end-user for } \\
\text { each regeneration scheme. Therefore, the public sector is the group } \\
\text { responsible for ensuring the sustainability of their area. The development } \\
\text { that is in line with the community decision will make them appreciate the } \\
\text { site more. }\end{array}$ \\
\hline
\end{tabular}

\section{Research method}

The research object located in Bandarharjo, North Semarang Sub-district, with an area about 40 hectares. Semarang Old Town is divided into buffer zone and core zone. This research is limited to the revitalised area, which is the core zone. This research uses the case study method to answer the research question. The data collection technique used primary and secondary data. The sampling of data source was conducted purposively through the competent respondents who were directly involved in the revitalisation of Semarang Old Town. The primary data primer was obtained from an in-depth interview with Semarang Old Town Management Board (BPK2L), Cultural Heritage Expert Team (TACB) and architect specialists in a heritage building in Semarang Old Town. Focus Group Discussion (FGD) was carried out with the Spatial Planning Agency (Distaru/ Dinas Tata Ruang) of Semarang, BPK2L, Urban and Spatial Planning (PWK) and documentation of field observation results. The secondary data has been obtained from literature study of journals and books relevant to the research theme, regulations on cultural heritage building revitalisation as well as data obtained from institutions in the form of the master plan of Semarang Old Town management. The data was then triangulated as valid data sources to answer the research question. The strategies were formulated from stakeholders' perspectives by corroborating of secondary data, FGD and interviews with selected experts in this research.

\section{Results and Discussion}

\subsection{The framework of revitalisation of heritage area: a case of Semarang City}

This research uses the case study method to answer the research question. The data collection technique used primary and secondary data. The sampling of data source was conducted purposively through the competent respondents who were directly involved in the revitalisation of Semarang Old Town. 
This research was reviewed from a wide range of issues in Semarang Old Town. The problems arising in Semarang Old Town has made it a dead town with minimum activities. Moreover, buildings with high historical values are about to collapse. The issues in Semarang Old Town include the social, environmental, Building and Institution Management issues. These problems can be prioritised based on the level of the problem. A management strategy is needed to address the problems. The Government and relevant stakeholders have tried to solve the issues in the past two decades, such as tidal floods which give negative image, crimes, prostitution, and slum area.

The management of Semarang Old Town revitalisation consists of planning, implementation, and monitoring. Each stage involves the parties who are directly engaged in the revitalisation process of Semarang Old Town and are competent as well as having insight in the heritage building. The task of each stakeholder is different from one to another, yet they have the same goal for a successful revitalisation process of Semarang Old Town. The responsibilities and authorities of the parties is presented in Table 3.

Table 3. Responsibilities of Stakeholder in Heritage Area of Semarang.

\begin{tabular}{|l|l|}
\hline \multicolumn{1}{|c|}{ Stakeholders } & \multicolumn{1}{c|}{ Responsibility and authority } \\
\hline Municipality of Semarang & $\begin{array}{l}\text { Regulating and handling all administrative affairs (regional autonomy) by the } \\
\text { principle of autonomy }\end{array}$ \\
\hline $\begin{array}{l}\text { Old City Management } \\
\text { Board (BPK2L) }\end{array}$ & $\begin{array}{l}\square \text { Managing, developing, and optimising the potentials of heritage area of } \\
\text { Semarang Old Town/ KKLS (area planning, monitoring and controlling) } \\
\text { Conducting some parts of conservation and revitalisation of KKLS }\end{array}$ \\
\hline $\begin{array}{l}\text { Cultural Heritage Expert } \\
\text { Team (TACB) }\end{array}$ & $\begin{array}{l}\text { Providing recommendation on determination, ranking, and removal of Cultural } \\
\text { Heritage (to the minister, governor, regent/ mayor) }\end{array}$ \\
\hline $\begin{array}{l}\text { Architect Specialist in } \\
\text { Heritage Building }\end{array}$ & $\begin{array}{l}\text { Handling and providing training of CHB conservation and assistance on } \\
\text { preservation works initiated by the community }\end{array}$ \\
\hline
\end{tabular}

Each stakeholder is responsible and participating in the revitalisation process of Semarang Old Town, yet they are connected to achieve the goals of revitalisation. Revitalisation process in Semarang old Town can be seen from the framework of revitalisation process implementation, which is the development of the problems in Semarang Old Town as formulated in Fig. 1. 


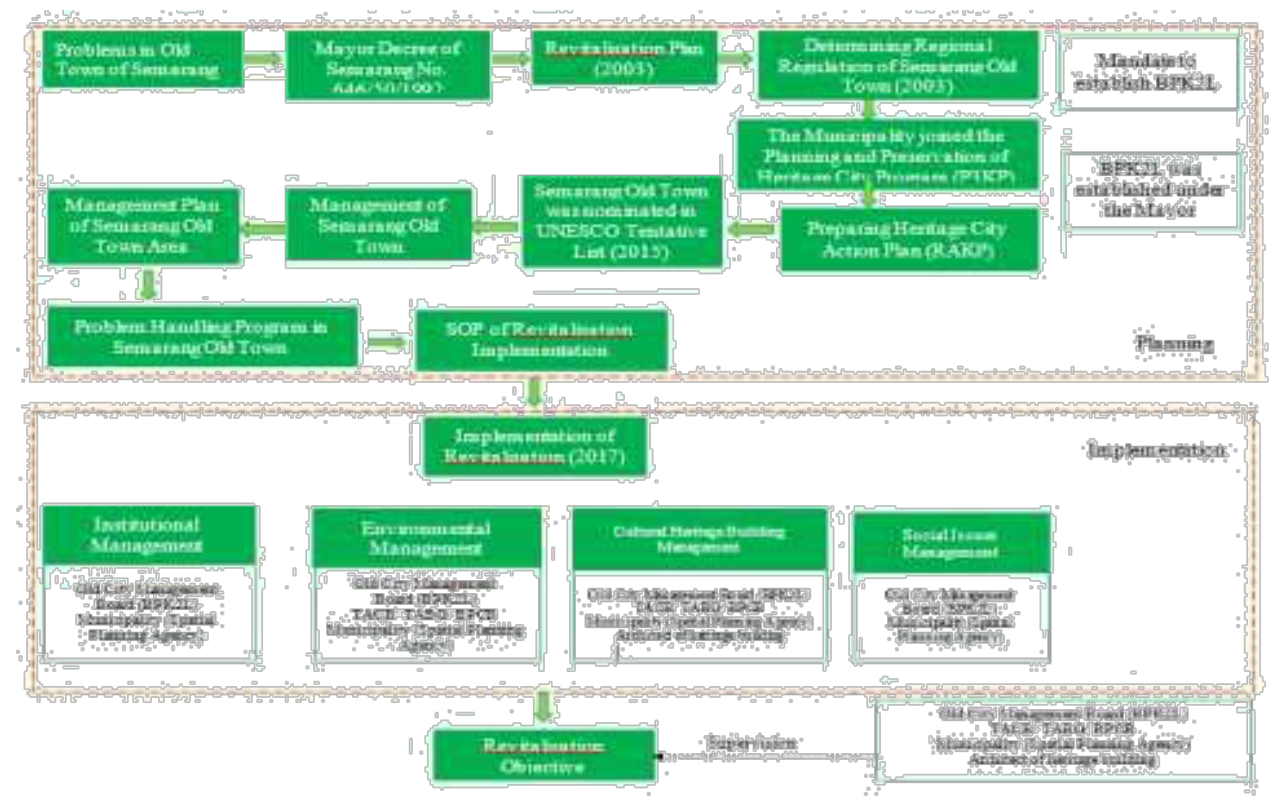

Fig. 1. Framework of Revitalisation Process of Heritage Area in Semarang by Stakeholders.

It can be seen from the framework that Municipality of Semarang and BPK2L have the dominant roles during the revitalisation stage of Semarang Old Town. Therefore, the internal conflict in BPK2L is considered as the main problem that must be resolved immediately, thus it will not disturb the revitalisation process. The Municipality of Semarang can support the revitalisation process by implementing policies that benefit all parties and have clear goals.

\subsection{Revitalisation design in Semarang Old Town}

The Municipality of Semarang wants to make Semarang Old Town a world-class cultural heritage (World Heritage) in 2020. World Heritage status is a status given by UNESCO to maintain and preserve both tangible and intangible cultural heritage which is unique and different from other countries. A historic city/ area must have an OUV (Outstanding Universal Value) to be able to hold world heritage status which differentiates it from other regions. OUV is culture and/ or nature that is considered having extraordinary meaning as a legacy that will always exist from generation to generation [6]. It means that OUV value will never be lost even though the time is rolling.

OUV is used as the criteria for assessing a world heritage. In assessing a world heritage to be nominated as world heritage it must meet the main three pillars; meet standards, integrity, and authenticity, and the last one is protection and management. UNESCO will assess the three main pillars that will support the OUV. However, in fact, Semarang Old Town encounters several obstacles to be able to hold the world heritage status, including:

Does not meet the OUV since it does not maintain its authenticity attached to the physical building. Museum DMZ 3D uses colourful paint material that is different from the conservation concept, and therefore reducing its authenticity. In addition, design implementation of the street furniture in the Old Town area are still three debatable issues: (1) It is not the one and only sugar trading town. Semarang Old Town is only controlling the trade and not as the sugar manufacturer; (2) Semarang Old Town is not the only colonial city based on the port, so if it stands alone failure is a certain thing since Jakarta Old Town is proven to fail. As the next step, Semarang Old Town is planned to be combined with Jakarta Old Town because they are port-based colonial cities. Yet, it is still 
being reviewed; and (3) Lack of cooperation and coordination of related parties while the community does not have a space to participate by preparing themselves as world community.

Semarang Old Town was successfully designated as a National Cultural Heritage after failing 4 times before because it was considered unable to present its values. The title of National Cultural Heritage was obtained because Semarang Old Town successfully proved its living culture through the history of Semarang. Semarang Old Town was the first city designated by TACB as a National Heritage City with the name Old Semarang, starting from the port, Malay village, Chinatown, Kauman village and Semarang Old Town. The title of national cultural heritage was also expressed several times in FGDs and in-depth interviews with the stakeholders.

A property may be said to meet the conditions of authenticity if its cultural beliefs are honestly and credibly expressed through a range of attributes. The current development shows that the revitalisation design of Semarang Old Town still raises many pros and cons, but its implementation cannot be delayed because it is mandated by the central government. The application of designs to buildings and areas is considered as not contextual as happens in the DMZ 3D museum located on Jalan Letjend Soeprapto. The exterior of Museum DMZ $3 \mathrm{D}$ uses colourful paint material that is different from the conservation concept, and therefore reducing its authenticity. Apart from the buildings, the design concept in the area also raises pros and cons as seen in Table 4.

Table 4. Pros and Cons of Revitalisation Design of Semarang Old Town.

\begin{tabular}{|l|c|}
\hline \multicolumn{1}{|c|}{ Pros } & Cons \\
\hline $\begin{array}{l}\text { 1. A valuable heritage must be maintained and preserved. Its } \\
\text { integrity value will be lost if it is physically damage } \\
\text { 2. The street furniture problems can be handled since the street } \\
\text { furniture is transferable }\end{array}$ & $\begin{array}{c}\text { 1. Revitalisation in the Old Town that is } \\
\text { currently lost its contexts such as the } \\
\text { presence of fountains, streetlamp } \\
\text { engineering, and excavation } \\
\text { 2. The revitalisation process in the Old } \\
\text { while the sidewalks are widened. So that it is comfortable } \\
\text { for the pedestrians }\end{array}$ \\
$\begin{array}{l}\text { 4. Bollard placement as a barrier between the sidewalk and the } \\
\text { road is used to change the community's habit to prohibit } \\
\text { vehicles run on the sidewalk. If the bad habit has changed, } \\
\text { re-arrangement will be carried out }\end{array}$ & $\begin{array}{c}\text { colourful, curved roads, lots of billboards, } \\
\text { lots of lights. So, an immediate discussion } \\
\text { on how to implement conservation } \\
\text { properly needs to be hold }\end{array}$ \\
\hline
\end{tabular}

Strategy is a way to achieve goals. The revitalisation implementation of Semarang Old Town has a vision towards world heritage with the aim of community welfare. In determining the revitalisation strategy, analysis is needed to support the development of an area. SWOT analysis includes Strength, Weakness, Opportunity and Threats which can support to develop an area. Through SWOT analysis, revitalisation strategy proposal for Semarang Old Town can be concluded seven strategies, as follows: (1) Improving human resources, in the form of education about the importance of preserving the values contained in CHB such as by story-telling about the important values of cultural heritage that can be used as guidance for the cultural knowledge. The community is expected to participate to become world community; (2) Dividing regional zones into several segmentations with various functions, so that the development in the area is not monotonous. Zoning can also increase income in the economic sector, for the activities do not overlap and to avoid business competition; (3) Design of the buildings must be in accordance with the conservation values and contextual with environment. Maintaining integrity and authenticity of the buildings in Cultural Heritage area. Therefore, during the 
implementation of revitalisation process, it must be continuously monitored and evaluated so that the restored buildings and areas are in line with the environment; (4) Maintaining integrity and authenticity of the buildings and the area. World heritage status is obtained if the authenticity of a property is integrated with other components. Therefore, the activities must maintain the integrity and authenticity values; (5) Improving the quality of the assisted environment. Quality improvement of the environment can be carried out by improving facilities and infrastructure. Facilities and infrastructure can be used as supporting elements to increase comfort and safety for the users. (6) RTBL must comply with the developed environmental condition. As a guideline for regional management planning, the RTBL must contain a detailed development plan. RTBL preparation must consider the current environmental conditions. Therefore, periodical review and evaluation are required and (7) Area management is carried out with top-down and bottom up system. Area management does not always have to be done with top-down system, where the Government has the authority to regulate and manage, but the community can also participate in realising the goals of revitalisation for a well-integrated (bottom-up) system.

\section{Conclusions}

Revitalisation management in Semarang Old Town was planned in 2003 but it could finally be implemented in 2017 until this research was conducted. The planning process until the implementation of revitalisation in Semarang Old Town was quite long. This was due to the obstacles in the form of internal conflicts among the management agencies and unclear duties and authorities of each stakeholder. Therefore, a management plan is needed to solve the problems in Semarang Old Town. The roles of each stakeholder also contribute to the success of revitalisation. Stakeholders who have the biggest role in the revitalisation process of Semarang Old Town are the Municipality of Semarang (Spatial Planning Agency), and BPK2L. It is based on the frequency of involvement in managing Semarang Old Town Area. In the process to be the world heritage, Semarang Old Town must facing some issues. It is expected that these problems can be solved as soon as possible, the world heritage title can be achieved. It is expected that the formulation of revitalisation strategy can become a reference for revitalising other historical areas in other regions.

\section{References}

1. S. Sari, A. Haran, H. Werdiningsih, H. MODUL 17,1(2017)

2. S. Septemuryantoro, LITE 13, 2 (2017)

3. B. Prabowo, B. Harsritanto, MODUL 18,1 (2018)

4. L. Purwanto, Dimensi Teknik Arsitektur 33, 1 (2005)

5. Massadun, Pengelolaan Kawasan Kota Heritage Pesisir Berbasis Pariwisata Kreatif Studi Kasus: Kawasan Kota Lama Semarang in Proc.Seminar Heritage, Semarang (2017)

6. WHC, Operational Guidelines for the Implementation of the World Heritage Convention. (France: UNESCO World Heritage Center, 2012)

7. H. Asmania, M. Musawa, J. of Pub. Adm., 1-10. (2013)

9. E. Santhika, https://www.cnnindonesia.com/(2018)

10. Rmol.id.,https://nusantara.rmol.id/ (2018)

11. L. Spina, I. Lorè, R. Scrivo, A. Viglianisi, MDPI, 1-25. (2017)

12. K. Al-Obaidi, S. Wei, M. Ismail, K Kam, MDPI, 1-18. (2017)

13. G. Cardani, P. Belluco, MDPI, 1-12. (2018) 
14. P. Rocha, R. Rodrigue, MDPI, 1-10. (2016)

15. M. Zagroba, Proc. Eng., 221 - 225 (2016)

16. A. Osello, G. Lucibello, F. Morgagni, MDPI, 1-12. (2018)

17. S. Said, H. Aksah, E. Dewiyana. Heritage Conservation and Regeneration of Historic Areas in Malaysia, Proc. Soc. and Bhv. Sci., 418-428(2013)

18. J. Moya, MDPI, 1-19 (2018)

19. HUL, Managing heritage in dynamic and constantly changing urban environments. Bad Ischl: The 15th World Conference of the League of Historical Cities (2016)

20. R. Pickard, Funding the architectural heritage: a guide to policies and examples. (Europe: C. of Eur. Pub., 2009)

21. D. Elsorady, Revitalisation of Downtown Khedive Cairo: A contested sovereignty. (Elsevier, 2017)

22. T. Ertan, Y. Eğercioğlu, The Impact of UNESCO World Heritage List on Historic Urban City Centers and Its Place in Urban Regeneration: The Case of Melaka, Malaysia and Tire, Turkey. Proc.Soc. \& Bhv.Sci, 591-602. (2016) 